\title{
A CONFIGURAÇÃO DA JUSTIÇA EM LÉVINAS: A IMBRICAÇÃO ENTRE DIREITO, POLÍTICA E ÉTICA COMO VIA PARA A PROMOÇÃO DO DESENVOLVIMENTO HUMANO E FORMA DE SE ALCANÇAR A PACIFICAÇÃO SOCIAL
}

Rafael Soares Duarte Moura

http://buscatextual.cnpq.br/buscatextual/visualizacv.do?id=K4208818H7

\begin{abstract}
Resumo: Serão desenvolvidas nos escritos seguintes algumas considerações referentes à configuração da justiça no relacionamento entre os Eus presentes na sociedade. Trata-se de uma reflexão sob a ótica do pensamento levinasiano/fenomenológico, visão de justiça essa enriquecida, igualmente, pelas correntes filosóficas e jusfilosóficas que se dedicam a esta tarefa.
\end{abstract}

Palavras-chave: Vida em sociedade; Alteridade; Configuração da Justiça.

The configuration of justice in Levinas: the interconnection among law, politics and ethics as a means of human development promotion and way to achieve social pacification

Abstract: In the writings following writings some considerations regarding the configuration of justice in the relationship between the selves in society will be developed. It presents a reflection under the optics of Levinasian/phenomenological thought, such vision of justice enriched also by philosophical and jus-philosophical that dedicates to this task.

Keywords: Life in society; Otherness; Configuration of Justice.

\section{INTRODUÇÃO}

Cabe, inicialmente, ressaltar que a dinâmica da configuração da justiça se apresenta no pensamento levinasiano com a entrada do terceiro no relacionamento entre o Eu e o outro.

Os terceiros não estão puramente ausentes do face-a-face, eles me olham no olhar de
outrem, mas não como outrem de fato, eles me olham sem me olhar, sem a retidão
insustentável que é aquela do rosto. [...] Com efeito, a multiplicidade dos homens, o além
de dois, os terceiros, são logo obrigados a pensar o que lhes é comum, o que faz sua
comunidade, o que deles apela a uma justiça. (grifo nosso) (BENSUSSAN, 2009, p. 75)

Dessa forma, “a justiça figura como (a) uma exigência por parte da outra pessoa que representa uma tradição "espiritual” da lei; (b) um julgamento que a responsabilidade permite ao eu fazer em um "surgimento" ou "nascimento" da consciência e (c) o julgamento de um terceiro sobre o relacionamento face a face.” (HUTCHENS, 2007, p. 139) 


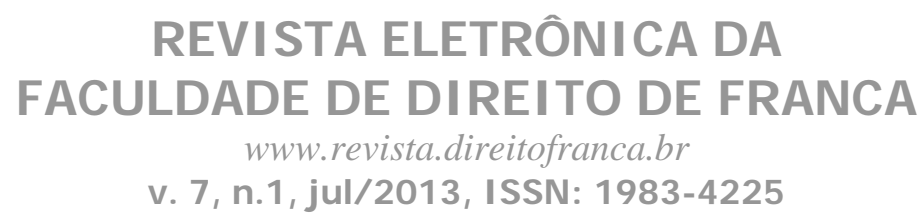

A presença do terceiro, de fato, suscita um posicionamento do Eu configurado como uma resistência ao outro, quando este e suas atitudes injustas alcançam ao terceiro ${ }^{1}$.

\begin{abstract}
O Outro não se opõe a mim como uma outra liberdade, mas semelhante à minha e, por conseguinte, hostil à minha. Outrem não é outra liberdade tão arbitrária como a minha, sem o que franquearia de imediato o infinito que me separa dela para entrar sob o mesmo

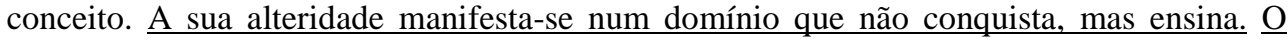
ensino não é uma espécie de um género chamado dominação, uma hegemonia que se joga no seio de uma totalidade, mas a presença do infinito que faz saltar o círculo fechado da totalidade. (grifo nosso) (LÉVINAS, 2008a, p. 165)
\end{abstract}

A dimensão do relacionamento estabelecido pela intriga ética proposta é efetivamente social. $\mathrm{E}$, quando se fala em dimensão social ${ }^{2}$, tem-se que o aspecto do relacionamento pautado pela ética ${ }^{3}$ se faz necessário, quando se pretende a materialização de relações configuradas pelo senso de justiça, na equidade, “essa melhor das justiças, segundo Aristóteles, porque é a que propicia a acomodação do fato com suas arestas e detalhes na adversidade e na diversidade à base rígida da norma feita para durar no tempo, no espaço e na contingência”. (LOPES,2012a, p.5)

A justiça é, ao mesmo tempo, garantidora e fruto de relacionamentos humanos pautados pelo senso da ética no agir. "É necessário assegurar que homem, desinteressado e dedicado ao outro como e santidade, possa ver viabilizada sua vida virtuosa em consonância com a universalidade da lei.” (RIBEIRO JÚNIOR, 2008, p. 91). A justiça apresenta, igualmente, acepções que se enriquecem em uma complementaridade visível, pois “ao lado dessa acepção originária - em que a justiça é superação do ser e sinônimo de generosidade, gratuidade e perdão - há também uma segunda que, aparentemente, parece contradizer a primeira; a justiça como medida, peso, equilíbrio, troca e igualdade; e como o conjunto das normas, das instituições e das leis que determinam a equidade dessa troca e a restabelecem quando é violada.” (DI SANTE, 2005, p. 77-78)

\footnotetext{
1 “A presença não acidental do terceiro na própria intriga ética revela a centralidade da questão da justiça para a filosofia da alteridade. Perguntar-se pelo sentido que a justiça - fruto do amor- assume no contexto do individualismo ético tem a sua razão de ser.” RIBEIRO JÚNIOR, 2008, p. 383.

${ }^{2}$ Neste sentido, convém ressaltar que, em meio ao desenvolvimento do pensamento levinasiano, nesta dimensão social “o paradoxo se torna mais acentuado ainda quando Levinas põe a socialidade na base da relação que constitui o estatuto ético: a dialogocidade não se constitui numa relação que se encerra no eu-tu, mas pela injunção do outro no mesmo, perturbando definitivamente a totalidade do eu, impelindo-o e fazendo-o abandonar o seu egoísmo, implicando como um- para- o- outro, elegendo-o como responsável.” (grifo nosso) MELO, 2003, p. 253.

3 “A ética levinasiana propõe pensar esta relação humana sob o modo do encontro, do inesperado, do acontecimento de um arrombamento e,mais radicalmente ainda, por via de consequência, como uma relação ao infinito, do qual o rosto, lugar do arrombamento, em sua nudez absoluta, seria o traço ou o não-lugar. O rosto barra toda definição. Definir o rosto equivaleria a esquecer o infinito que ele significa e na finitização de sua definição.” (grifo nosso) BENSUSSAN, 2009, p. 17.
} 


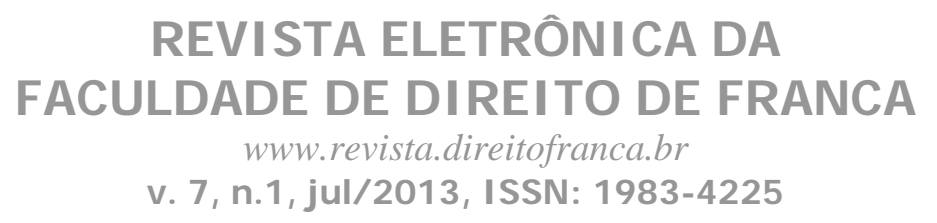

A lei figura como elemento garantidor, possibilitador social, de que os relacionamentos pautados pela virtude e pelo Bem possam existir e se desenvolver sem serem obstruídos por comportamentos de violência para com essas relações estabelecidas.

A lei não pode ser vista como um elemento acabado, confundida com a justiça, mas deve ser reflexo, e promotora primeira, desta. Os órgãos que implementam, por meio da estrutura de um Estado, a produção legislativa e a sua aplicação, estão, de fato, em contínuo aprimoramento estrutural e valorativo, ou, pelo menos, deveriam estar, justamente visando proporcionar, mediante as competências que lhe são conferidas pela Constituição, a criação de leis que norteiam as decisões judiciais e os atos da vida civil, como um todo, do senso de justiça, sempre buscado pelo humano em sua trajetória existencial.

\section{O TERCEIRO COMO ESPELHO DA SOCIEDADE: A VULNERABILIDADE EXIGENTE DA CONCRETIZAÇÃO DA JUSTIÇA PELAS INSTITUIÇÕES SOCIAIS.}

A conduta ética deve ser compreendida sob a ótica da configuração do diferente presente no rosto do outro. O ser ético está imbricado ao ato de responder, que implica em responsabilidade ao que a demanda no relacionamento face-a-face. Alguma resposta tem que ser dada necessariamente, incluindo-se nesta o silêncio ou o ato injusto que se configura como uma resposta desprovida da responsabilidade ética.

Não há tempo para se conjecturar hipóteses e consequências do responder, fato esse que poderia desvirtuar a eticidade da resposta em condicionamentos pautados pelo interesse egoístico que inobserve a necessidade de um posicionamento premente e que exige uma imediata réplica.

Antes mesmo de constituir uma filosofia da alteridade, a ética levinasiana implica, pois, um
pensamento da subjetividade em sua estrutura respondente. [...] A subjetividade, trazida
pelo outro que transpassa seu mesmo, é estruturada como tendo-que-responder. [...] O estar
na obrigação de responder, imemorial, vem de muito longe, bem antes das questões que eu
possa me colocar sobre as razões pelas quais eu respondi ou eu não respondi. E,
freqüentemente, enquanto estou a pesar os prós e os contras, é já muito tarde, o tempo da
resposta passou, o tempo do pensamento e da pesagem veio aboli-lo (grifo nosso)
(BENSUSSAN, 2009, p. 25)

Se à ética se associa a necessidade da responsabilidade para com o outro, a moral será a articuladora do relacionamento entre o Eu e o terceiro, tendo em consideração a reciprocidade desse relacionamento. 


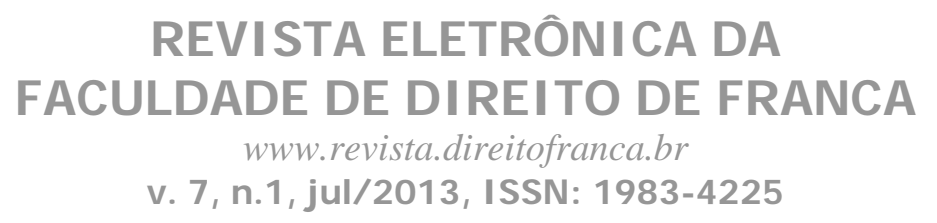

No sentido em que Ricoeur utiliza a distinção entre a ética (bem-viver) e a moral (dever). Analogamente, a ética diria respeito à necessidade da responsabilidade pelo rosto, e a moral diria respeito à normatização dessa responsabilidade quando a relação com o próximo do meu próximo institui a reciprocidade nas relações e, conseqüentemente, a necessidade de articular ética e política. (RIBEIRO JÚNIOR, 2008, p. 91-92)

Tem-se que ter em destaque que a dinâmica interativa entre o Eu e o outro não se apresenta da mesma forma e a necessidade da configuração da justiça, por meio das instituições dispostas e construídas pela sociedade, representa um clamor por resposta imediata ${ }^{4}$. Dessa forma, o alinhamento entre a política, a atividade legislativa, a judicial e a executiva com a ética proporcionará uma visível implementação da pacificação social, por meio da regulamentação pragmática de leis que sejam "letras vivas” e se aproximem do senso do justo. "A política tende ao reconhecimento recíproco, isto é, à igualdade; assegura a felicidade. E a lei política completa e consagra a luta pelo reconhecimento.” (LÉVINAS, 2008a, p. 52)

Ressalta-se que não escapa ao pensamento de Lévinas a extrema vulnerabilidade do outro em face do Eu que se aproxima. Ínsita se apresenta a noção de intriga ética, na qual essa vulnerabilidade, que pode ser oportunidade para a configuração do mal, que seria um desrespeito a este outro, poderia alcançar a um terceiro.

Minha resistência começa quando o mal que me faz é feito contra um terceiro que é
$\underline{\text { também meu próximo. É o terceiro que é fonte da justiça e, por ai, da repressão justificada; }}$
é a violência sofrida por terceiro que justifica que se pare com violência a violência do
outro. A ideia de que sou responsável pelo mal feito pelo outro - ideia rejeitada, reprimida
mesmo que psicologicamente possível - conduz-nos ao sentido da subjetividade. [...] A
ideia de substituição significa que eu me substituo a outrem, mas que ninguém pode
substituir-me enquanto eu. Quando se começa a dizer que alguém pode substituir-me,
começa a imoralidade. (grifo nosso) (LÉVINAS, 2008b, p. 120-121)

Faz-se, consequentemente, necessário a existência de estruturas sociais e legais que atuem na gratuidade desinteressada, de forma a evitar quaisquer formas de violência ao outro e ao terceiro.

o surgimento do “terceiro homem” traz uma novidade problemática, não apenas para a proximidade, mas de modo ainda mais abrangente para tudo aquilo que significa referir-se à ética da alteridade. [...] a filosofia da alteridade vê-se impelida a ter de pensar sobre a necessidade das estruturas sociais e do Estado legitimamente reconhecidas como capazes de conter a violência. (grifo nosso) (RIBEIRO JÚNIOR, 2008, p. 91)

Depara-se com o resultado possível da intriga ética levinasiana, qual seja, diante do outro que se aproxima, em sua vulnerabilidade, ao Eu é facultado fazer ou não o mal a este outro. Porém,

\footnotetext{
${ }^{4}$ Para maior aprofundamento, Cf. O’NEILL, Onora. Em direção à justiça e à virtude. Uma exposição construtiva do raciocínio pratico. São Leopoldo: Unisinos, 2006, p. 181-215.
} 


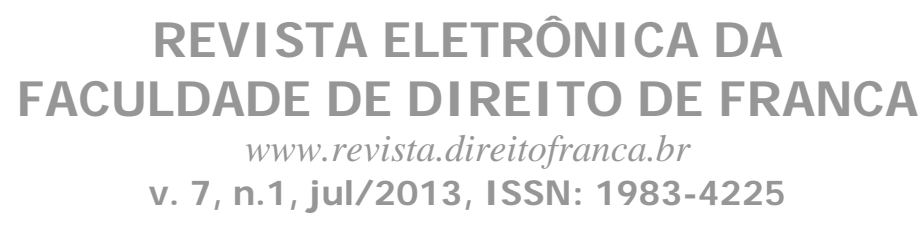

tendo em consideração que o Eu é parte integrante de um sistema social no qual há aceitação, ainda que tácita, dos arranjos normativos que regulamentam o mesmo, poderá esse Eu ser julgado caso opte por invadir a esfera de direitos deste outro que se aproxima. Dessa forma,

\begin{abstract}
$\underline{\text { A justiça soluciona a rede de responsabilidades infinitas apenas porque o eu chega a }}$ reconhecer arranjos sociais pré-existentes e é julgado por um terceiro em responsabilidade. [...] A própria consciência nasce da percepção da injustiça e da demanda por justiça. $\underline{A}$ justiça soluciona a responsabilidade no sentido de que a vulnerabilidade e a obsessão do eu agora são julgadas por alguém que não é parte do relacionamento face a face e não tem qualquer interesse nele. (grifo nosso) (HUTCHENS, 2007, p.140)
\end{abstract}

A imparcialidade deste julgamento se vê garantida pelo aparecimento do terceiro que, como não partícipe da relação conflituosa, promoverá um julgamento desinteressado, reflexo unicamente da responsabilidade.

Atenta-se, neste momento que a imparcialidade está diretamente relacionada com o reconhecimento do outro. Não se faz possível o estabelecimento da justiça se a imparcialidade repousa sobre um rosto anônimo e desconhecido. Quando ela resulta de um mero formalismo no ato de se procurar fazer a justiça.

A demanda por justiça inclui, ao lado de outras dimensões, uma demanda por reconhecimento e que, se o reconhecimento sem imparcialidade é injusto, inversamente, a imparcialidade sem o reconhecimento também o é. [...] a demanda por reconhecimento é uma demanda por imparcialidade, mas interpretada em termos respeitosos à singularidade, em termos, portanto, de equidade, e não de negação da diferença como sonhava Rousseau.[...] somente a imparcialidade não é suficiente, que a demanda por justiça deve incluir a demanda por reconhecimento, o que justifica as políticas de discriminação positiva, a recusa da igualdade simples, da paridade para as mulheres, etc. e introduz o perigoso pólo da diferenciação no centro da justiça. (AUARD, 2006, p. 94-96)

Destaque-se que essa divisão feita entre outro, Eu e terceiro não deve ser pensada como estática, pois um homem pode figurar-se como qualquer um deles. Esse é um fato constatado pelo dinamismo próprio da sociedade em que:

o seio da relação eu-outro a chegada do Terceiro representa o rompimento da dialogicidade governada pelo Eu. Afirma-se que essa inspiração levinasiana funda uma compreensão de relação intersubjetiva, um novo humanismo ético-social. A aparição do terceiro, no seio da relação imediata entre o eu e o outro [...] indica-nos algo mais: na prática da caridade, do amor desinter-esse pelo próximo, vive-se um ideal ético-humanista. [...] $\mathrm{O}$ fato de o outro-meupróximo ser também um terceiro em relação a um outro, que também é próximo, revela uma cadeia de relações que implica abertura do um-para-o-outro para o infinito. A minha responsabilidade não é limitada pela responsabilidade do outro; somos todos implicados, somos todos culpáveis, todos responsáveis. A tomada sobre si do destino do outro é o elo de ligação da coexistência entre o eu-outro-terceiro e outro, para quem sou o próximo e o terceiro. [...] Pela entrada do terceiro, praticamente, começa a gênese levinasiana da sociedade: a metafísica ou relação com o Outro realiza-se como serviço e como hospitalidade. Na medida em que o rosto de outrem nos põe em relação com o terceiro, a relação metafísica entre Mim e Outrem vaza-se na forma do Nós, as pira a um Estado, às 


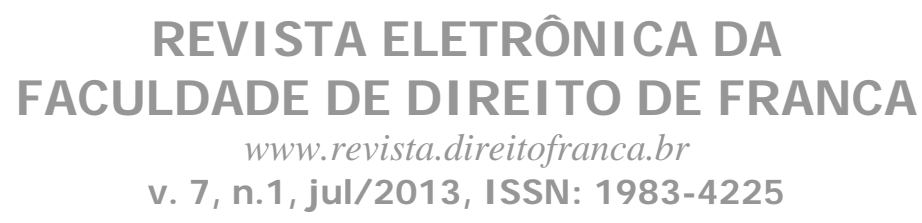

Instituições, as leis, que são fonte de universalidade. (grifo nosso)( MELO, 2003, p.256257)

Assim, se, por acaso de reflexão, surgir o questionamento sobre a (não) configuração da justiça na dinâmica do relacionamento entre o Eu e o outro, como justificativa de que apenas se pode pensá-la quando do aparecimento do terceiro, essa argumentação restaria invalidade com a ideia de que os indivíduos figuram em polos de representação distintos em cada relacionamento desenvolvido.

Ao outro não é facultado o desrespeito ao $\mathrm{Eu}$, como se deste desrespeito não surgisse nenhuma resposta ao clamor pela materialização da justiça e contenção da violência feita. Tem-se que, na medida em que o Eu pode ser também o outro e um terceiro, ter-se-ia a necessidade de implementação da justiça não apenas quando os efeitos da violência atingissem ao terceiro.

O terceiro representa a sociedade e não apenas uma subjetividade encerrada em um homem. A sociedade, como coletividade da qual todos os Eus são parte, figura como catalisadora que impele à busca pela justiça, pautada pelo acolhimento do rosto que conduz a uma igualdade na diferença de cada um, resultando, assim, no estabelecimento de uma convivência pautada pela fraternidade.

\footnotetext{
Toda a relação social, como uma derivada, remonta à apresentação do Outro ao Mesmo, sem qualquer intermediário da imagem ou de sinal, unicamente pela expressão do rosto. A essência da sociedade escapa se é apresentada como semelhante ao género que une os indivíduos semelhantes. [...] É a minha responsabilidade em face de um rosto que me olha como absolutamente estranho - e a manifestação do rosto coincide com esses dois momentos- que constitui o facto original da fraternidade. [...] No acolhimento do rosto (acolhimento que é já minha responsabilidade a seu respeito e em que, por consequência, ele me aborda a partir de uma dimensão de altura e me domina), instaura-se a igualdade. (grifo nosso) (LÉVINAS, 2008a, p. 209)
}

Eis que se faz por imperioso ressaltar que a noção de intuição e a discussão sobre a configuração da justiça no relacionamento entre alteridades se pauta por uma concepção de heteronomia na configuração da subjetividade humana e no relacionar-se desta com outras.

Quando se fala em autonomia e heteronomia e suas conceituações, tem-se por relevante fazer algumas considerações:

Um povo livre é aquele que, fazendo um contrato consigo mesmo, obedece às leis políticas criadas por uma vontade geral reconhecida por cada cidadão. [...] A ideia de liberdade aparece intrinsecamente ligada à de autonomia e à de heteronomia.[...] Levinas define 0 primado ético sem considerar a liberdade do Eu como projeto fundante. [...] A liberdade investida encontra-se longe de uma compreensão da heteronomia reduzida ao totalitarismo do eu. Levinas prefere seguir a tradição hebraica que concebe o sujeito autônomo diante de uma exterioridade absoluta.[...] A autonomia se define, desse modo, a partir da heteronomia; a heteronomia vem do amor, e esta por sua vez, não é contrária a liberdade, mas por ela o sujeito e convocado, interpelado à bondade.A moralidade não é fundada, 


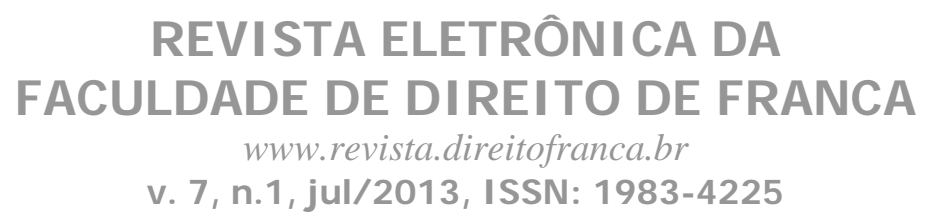

portanto , sobre a autonomia da razão, mas na orientação da Palavra, que precede e ordena cada pessoa na via do Bem. O sentido de heteronomia, para Levinas, orienta-se para uma responsabilidade pelo outro. (grifo nosso) (MELO, 2003, p. 262)

Dessa forma, tem-se que "uma sociedade regida por um Estado implicaria uma obediência, uma substituição da autonomia pela heteronomia”, por meio da qual a visão de subjetividade do humano se afasta de uma concepção plasmada pela autonomia egológica (MELO, 2003, p. 235238).

A autonomia deveria ser compreendida não como referente de um ser isolado, mas como aquela autonomia que não está só no mundo e que surge do e no diálogo com os demais participantes do mundo da vida. A autonomia seria construída na heteronomia, e não no sentido liberal excludente. (GUSTIN, 2010, p.13)

A autonomia em si não é má, pelo contrário, é condição necessária para que possa haver o "pôr-se-diante-de" no diálogo interacional. Essa autonomia não se confunde com a sua manifestação negativa, ou seja, egolátrica. A boa autonomia representa a dimensão satisfativa que a proporciona, vivida em cada dimensão do Eu e do outro, de forma que, a cidadania seja verificada quando se encontram presentes na vida do indivíduo o fruir dos bens materiais, para uma sua digna sobrevivência, e a possibilidade realocar esforços que, não mais alocados na busca pelos recursos materiais a subsistência, possam ser envidados a outras realidades que contribuem para o crescimento do homem, como a educação, elementar para a formação cidadã e o lazer. Ter-se-ia, dessa forma, uma autonomia que “deve orientar-se não somente num sentido restrito de satisfação de carências materiais, mas de atribuir aos cidadãos a capacidade de se autorregerem e de participarem com autonomia crítica da sociedade, tanto no que se refere à ação quanto à capacidade argumentativa.” (GUSTIN, 2010, p.13)

A autoridade da lei do estado ou das instituições republicanas são entendidas, por Levinas, como leis inventadas pelos homens, [...] para que os homens vivam entre si sem se destruírem.O momento da invenção da lei e da sua recepção é vivido de maneira particular,por cada indivíduo, como se a lei se dirigisse a cada um, na sua singularidade e unicidade. A adesão de Levinas às leis da república se volta unicamente para a noção de Bem, que ele concebe na perspectiva da Eleição.Para Chalier, isso significa que Levinas concebe a autonomia do sujeito na medida em que este, entendendo as exigências, as assume com um dever imperativo a responder. A compreensão da heteronomia no conjunto do discurso levinasiano, é iluminada sempre pela epifania do Rosto do Outro, enquanto Próximo; o Próximo é pessoal, ele é o rosto do pobre, do estrangeiro, da viúva e do órfão, 0 Próximo- Mestre chamado a investir e justificar a liberdade. Na relação face-a-face Levinas põe a impossibilidade da liberdade e/ou de uma autonomia do sujeito que se autocompreende como razão de todas as suas escolhas e como autodeterminação da Lei. (grifo nosso) (MELO, 2003, p. 262) 


\section{REVISTA ELETRÔNI CA DA FACULDADE DE DIREITO DE FRANCA \\ www.revista.direitofranca.br \\ v. 7, n.1, jul/ 2013, I SSN: 1983-4225}

Subjetivismo é sempre um ponto a ser refletido com maior aprofundamento. Mesmo porque, no pensamento levinasiano não se conceberia o estudo da subjetividade que não fosse ligado ao da ética. Esta está em função do humano e suas relações interpessoais. “A ética não existiria fora dessa perspectiva. A socialidade não constitui uma estrutura diversa, uma unidade de sujeitos, uma simples comunhão de pessoas iguais, mas a constituição de uma nova ordem que se dá na órbita do outro. No nascimento latente da subjetividade, dá-se o surgimento de uma sociedade: o sujeito é despertado para a imediatidade do um-para-o-outro, para a responsabilidade.” ( MELO, 2003, p. 253)

Consequentemente, não se pode pensar em ética ${ }^{5}$, diretamente imbricada à concretização da responsabilidade, sem antes pautar-se a concepção de subjetividade em uma sociedade na qual a dinâmica das relações e disputas pelo poder, não apenas político, mas econômico, acadêmico, familiar, etc., se apresentam como um elemento de dominação e de formação identitária que pode promover a exclusão. Essas disputas de poder puderam ser constatadas pela:

inteligência moderna que, em Auschwitz, viu o resultado da lei e da obediência decorrente do ato heróico - nos totalitarismos, facistas e não facistas, do século XX. A inteligência moderna tem suas razões, mesmo que Razão eterna deva um dia renegá-las. Ela esgota-as nas lembranças bem recentes - e na atualidade ainda atual - em que a deficiência humana perdeu sua modalidade de exceção na submissão à propaganda, ao terror, a todas as técnicas do condicionamento em que a onipotência dos homens se mostrou correlativa à certeza de que se pode tudo fazer do homem. (LÉVINAS, 2008b, p. 74-78)

\footnotetext{
“‘É necessário realmente sustentar que a ética, no sentido extra-ordinário de Levinas,designa uma estrutura pré-original da subjetividade que a engaja ao montante dela mesma, de alguma maneira, numa resposta pré-original e an-árquica, numa imemorial antecedência a si. [...] não fazer acepção de pessoa é precisamente a regra que se impõe e que autoriza a igualdade de todos e o tratamento imparcial e indiferente dos casos e litígios desde que certamente dita regra se articula a partir de um consentimento prévio e universal a um mesmo código de valores e de comportamentos. A responsabilidade ética descreve, ao contrário, um tipo de situação- limite, não obstante banal e quotidiana, na qual a autonomia do sujeito respondente se acha sobrecarregada e onde este é despojado da sua capacidade de iniciativa,sem mesmo que ele o queira. É-lhe necessário inventar a regra de seus atos no instante ou, mais exatamente, agir na “tomada”, como diz Levinas, precedendo toda a regra. É o que se poderia chamar de instante ou instantaneidade éticas. O instante ético, o instante da resposta,significa um abalo por um tempo diacrônico, por uma imediaticidade, um tempo que passa e se passa antes de toda tomada de consciência, antes de toda presença de espírito: o instante em que, sem preparação prévia, sem saber,sem poder, sem querer, um homem que se deixa inquietar pela transcendência de outrem, por sua irrupção inesperada que exige imperativa e imperiosamente uma reposta de responsabilidade, uma exposição do sujeito a um acontecimento que o invade, o constrange e o surpreende - ou o inibe, ao contrário. [...] O fazer éticoprático instantâneo interrompe a instituição e o formalismo das leis e dos Estados que ele precede. Assim, confrontado ao assassinato, o filósofo de Rousseau chamará a polícia, o que não é, de maneira alguma, repreensível, mas suspende a responsabilidade ética e a converte, arruinando-a, em responsabilidade civil. Este fazer,por sua vez, deverá ser diacronicamente interrompido pela justiça e a ordem da simetrização.” (grifo nosso) BENSUSSAN, 2009, p. 52-53.
} 


\section{REVISTA ELETRÔNI CA DA FACULDADE DE DIREITO DE FRANCA \\ www.revista.direitofranca.br \\ v. 7, n.1, jul/ 2013, ISSN: 1983-4225}

Percebem-se três palavras que muito traduzem a crise do humanismo ${ }^{6}$ apontada por Lévinas, quais sejam: submissão, condicionamento e individualismo. Esses verbos refletem preocupantes inclinações do homem que, em nome de um aparente poder, ilusão decorrente de uma concepção estreita de reconhecimento social, pode-se valer, e ainda o pode atualmente, de verdadeiros artifícios de controle e manipulação de seus semelhantes ${ }^{7}$. Estes artifícios de dominação foram e são utilizados via recursos midiáticos cada vez mais refinados, de forma a espraiar pela sociedade simulações do que é certo e errado. Uma tentativa de universalização de visões de um ou de muitos poucos.

Essas simulações são acompanhadas, ainda que subliminarmente, por ideias que induzem a massificação comportamental verificada, muitas vezes, pela padronização do consumo, do trato social, da visão política, da estrutura parental, dentre outros. Plantada se encontra a ideia de que o diferente, enquanto tal, não se adequando aos costumes “padronizados” de uma sociedade, deva ser, pelo menos, visto com um olhar diferenciado, notadamente tendente a pré-conceituações indevidas e violentas à liberdade desse diferente. Essa crise decorre da busca a todo e qualquer custo de uma proeminência social que, por vezes, inescrupulosamente, utiliza-se de artifícios vários para ascender como formadores de opinião e definidores dos rumos político-econômicos da sociedade.

A coisificação do homem pelo próprio homem não raramente foi constatada nessa pretensiosa corrida pelo poder. Porventura, se o homem ou agrupamentos dele, apesar de semelhantes aos outros na genética do homo sapiens, porventura se coloquem como uma voz que destoa dos interesses dos que vivem essa dinâmica pela ascensão ao poder, seriam os mesmos reduzidos a objetificação, ou, como se pode dizer, coisificação. Perceba-se que essa redução seria um claro artifício para que, com a sua pseudodesumanização proposta, pudessem eles ser eliminados da estrutura social sem maiores entraves éticos pelos outros, controladores ou manipulados pelo controle apresentado pelos grupos de poder. Claro está a alienação a que chegou o homem no horizonte do existir histórico.

\footnotetext{
${ }^{6}$ Para reflexão aprofundada e diálogo crítico sobre a temática, Cf. ROSENZWEIG, Franz. El nuevo pensamiento. Madrid: Visor, 1989.

7 "Em todos os tempos, mas especialmente hoje, o ser mais profundo do homem se rebela contra uma filosofia utilitarista, contra o conceito de uma humanidade manipulada, contra um mundo anônimo e contra todas as tendências de reservar aos especialistas, sejam cientistas ou políticos, o encargo de determinar o futuro da humanidade sem uma inteligente compreensão do significado da existência humana.” (HÄRING, 1974, p. 11)
} 


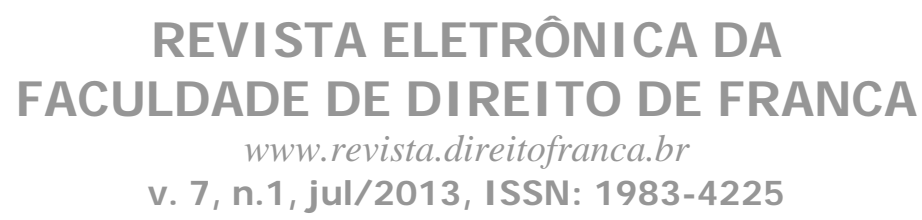

Desumanizados pela delegação dos poderes, os homens buscavam a exaltação do poder e, assim, não só as vítimas estavam desumanizadas, mas também os que comandavam. A rigor, estes eram instrumentos de um mecanismo, de uma dialética, de um sistema, do dinheiro. Pode-se dizer que eles não colocavam em causa os axiomas da própria análise marxista, a qual reconhecia, a uma só vez, os fatos da alienação e dos condicionamentos em função das estruturas econômicas e, assim, apesar das convulsões sociais diante das quais a simples vontade livre confessava sua impotência, tal análise juntava-se ao otimismo humanista ao anunciar uma humanidade triunfante em estado nascente, graças a uma lucidez integrante e à utilização dessas convulsões como necessárias à eficácia humana. ( LÉVINAS, 2008b, p. 74-78)

Alienação provocada por ele, que prefere não enxergar as abominações cometidas em nome de falsos ideais de nação, Estado forte, raça superior, democracia social e prosperidade econômica. A acomodação ensimesmada é mais interessante do que a verbalização que denuncie a loucura humanitária cometida por regimes políticos e econômicos. A mesquinhez a que chegou muitos homens provocou a desfiguração da sua própria humanidade.

\begin{abstract}
O fenômeno do estalinismo e as reincidências dos conflitos nacionalistas entre Estados que entraram na via do socialismo conferiram às possibilidades de degradação humana uma significação diferente daquela que esta poderia receber a partir de uma barbárie inocente, das faltas originais ou não originais e do divertimento. O sucesso das teses psicanalíticas nesse período que segue a derrocada - pelo menos provisória - do fascismo (sucesso, ele próprio explicado pela lembrança do totalitarismo) habituou-nos à ideia dos traumatismos não mediatizados e de uma influência insuspeita sobre a liberdade, a uma sondagem clandestina de uma humanidade desarmada, a procedimentos nos quais a razão se lavrava com os cérebros e não se assemelhava mais à unidade da apercepção transcendental nem a uma razão prática. (LÉVINAS, 2008b, p. 74-78)
\end{abstract}

Não se pense que essa realidade está afastada dos primórdios do terceiro milênio. Ela está mais do que presente nas várias mazelas que ainda soçobram a humanidade com corrupções, genocídios, cartéis econômicos, catástrofes alimentares e de saúde, dentre tantos outros fatos sociais que demonstram o quanto é premente resgatar a humanidade do próprio homem.

Resgate que não se restringe a noção de um Ser ideal, uma humanidade abstrata e conceitual, mas que se amplia pela visualização do homem concreto, vivente, que procura desde o nascimento até o seu ocaso apreender vida e aprender a viver. Este que busque se pautar pela coexistência em respeito e reconhecimento com o seu semelhante-que-diferente.

A essência do homem não pode manifestar-se em indivíduos isolados, porque as relações da pessoa humana com a sua geração e a sua sociedade são essenciais. Por isso, se quisermos conhecer a essência do homem, deveremos conhecer a essência daquelas relações. (BUBER, 2004, p.62)

O conceito do homem se emancipa do ego cogito descartiano da autossuficiência individualista do Eu que reina sobre si e vive uma solidão existencial. A desconstrução do 


\title{
REVISTA ELETRÔNI CA DA FACULDADE DE DIREITO DE FRANCA \\ www.revista.direitofranca.br \\ v. 7, n.1, jul/ 2013, I SSN: 1983-4225
}

individualismo egolátrico representa a emancipação do indivíduo que assume uma posição diferente do Eu sedutoramente ensimesmado que, encastelado, gozando de seu individualismo, deste torna-se refém. O homem se encontra, dessa forma, por meio do outro. Eis a ontologia preciosa levinasiana.

\section{A FORMAÇÃO DA IDENTIDADE: A SUBJETIVIDADE COMO POSSIBILIDADE DO AGIR ÉTICO NA COEXISTÊNCIA COM O OUTRO}

A noção de subjetividade esta imbricada a concepção do sentido na existência social. Temse que o ser humano, como indivíduo social, imerso em uma complexidade de costumes, relações e dinâmica cultural, apresenta-se como agente e, ao mesmo tempo, resultado do desenvolvimento da sociedade. “A importância do contexto cultural vem daquilo que permite regenerar os processos de identificação e de reconhecimento sem os quais o Eu é atomizado ou reificado, perde todo o sentido de seu valor e de sua dignidade.” (AUARD, 2006, p. 92). Este desenvolvimento denota clara relação de interdependência entre os homens. A essa relação se aplica a noção de subjetividade levinasiana que se apresenta, na sua dimensão heteróloga, como compromisso de assunção de uma responsabilidade que não pode ser delegada. O Eu se compreende, também, pela presença do outro que, reduzida pela substituição, tem sua percepção claramente captada pela intencionalidade do Eu.

\begin{abstract}
A heterologia não anula a subjetividade responsável pelo outro, embora nem por isso a subjetividade possa ser dita como autonomia. Ela não é autônoma no sentido que esse termo assumiu no humanismo ou no antropocentrismo da filosofia ocidental. Mas, por outro lado, ela é paradoxalmente autônoma. Ela é única, insubstituível, capaz de responsabilizar-se inteiramente pelo outro. A subjetividade é autônoma, porque ela não depende do outro, não está à mercê do outro, nem carece dele, para que possa amá-lo responsavelmente. Sua responsabilidade não é imposta pelo outro. Na afecção, o sujeito encontra-se numa situação tal que não pode não se ver mergulhado na condição de substituição do outro. (grifo nosso) (RIBEIRO JÚNIOR, 2008, p. 377.)
\end{abstract}

Configura-se, assim, a identidade do Eu a partir de um complexo de dois condicionantes que influem na formação dela, quais sejam, a sociedade e a existência mesma do indivíduo que, como que por inspiração, inova e procura se autodefinir enquanto existência. Seria uma forma paradoxal o processo de formação identitária, na qual se apresentam fluxos internos e externos que moldam o humano em sua trajetória. Esse amoldar-se apresenta-se, portanto, como resultado único dessa interação. Pode-se dizer que:

junto com a dimensão criativa do sem fundo-humano que auto-institui o modo de ser da subjetividade, o poder instituinte que a sociedade estabelecida exerce sobre o sujeito a 


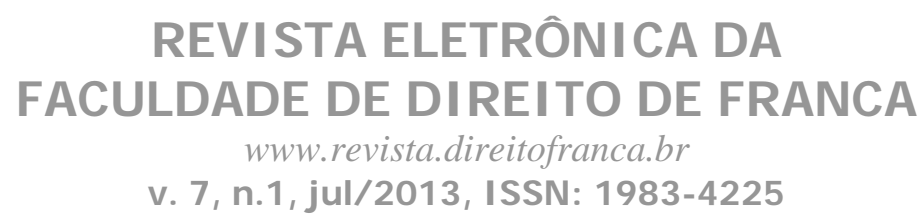

ponto de fazer de cada subjetividade um sujeito social determinado com uma identidade. Essa identidade se define pelas características de uma cultura e pelos interesses das instituições. Potencialidade criadora da subjetividade e poder instituinte da sociedade interagem de modo tenso, porém produtivo, na constituição de cada sujeito. (BARTOLOMÉ RUIZ, 2006, p. 126)

O resultado desse amoldar-se é único exatamente porque o processo de interação resulta em cada Eu uma compreensão, uma assimilação e uma criação distinta. Eis a alteridade levinasiana que se desenvolve pela constituição de signos que lhe são próprios e que proporcionam a constituição do sentido do viver.

A identidade pessoal nada mais é do que uma rede significativa construída em torno de si mesmo. A partir dela o sujeito se autocompreende em referência a história e às circunstâncias que vive. A subjetividade se insere nas diversas esferas do mundo através da prática do sentido. O sujeito, por meio da prática significativa, interage criativamente com todos os elementos, com as outras práticas, com os valores estabelecidos, com as instituições e com as outras pessoas. (BARTOLOMÉ RUIZ, 2006, p. 127)

A formação da identidade compreende, portanto, o exercício do sentido do existir pautado pela resultante do processo de interação com o mundo, com a consequente constituição dos signos que simbolizarão a visão do existir de cada pessoa. Percebe-se que a constituição do agir ético e, consequentemente, da concretização do ser justo, derivam do processo de formação identitária de cada humano. Se o sujeito representa "o resultado de sua própria interação com a realidade que vive” (BARTOLOMÉ RUIZ, 2006, p. 128), tem-se que:

é a mesma prática que institui a subjetividade e constrói simbolicamente o mundo em que habita. Prática, sentido e símbolo são os modos próprios da potencialidade criadora do semfundo-humano. A subjetividade se auto institui como tal na medida em que cria, se apropria e utiliza essas dimensões. (BARTOLOMÉ RUIZ, 2006, p. 128)

Com a contínua constituição da subjetividade do Eu, seguindo a linha levinasiana, segundo a qual a compreensão do Eu se define pela presença do outro que o interpela, configura-se a responsabilidade do $\mathrm{Eu}$, diante do processo relacional de formação contínuo, para com a diversidade humana presente na sociedade.

Relações humanas não se organizam esquematicamente. Vidas tocam-se e cravam na memória de cada um e de todos a marca desta realidade primaz que fica no relato da passagem pelo tempo. Relações humanas, relações jurídicas circulam com a lógica do caleidoscópio. E os seus tempos vão se alternando como se não houvesse começo, meio e fim, mas um moto contínuo em que diversidade e adversidade se misturam com imponderabilidade e imprevisibilidade. (LOPES, 2012, p. 3)

Dessa forma, a noção de coexistência de subjetividades no locus social se apresenta como o desafio das instituições constituídas pela sociedade com a finalidade de viabilizar uma convivência 


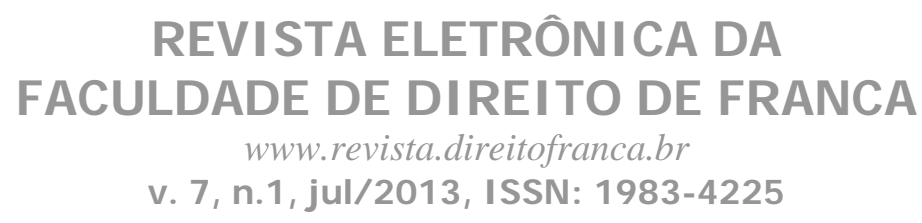

que se afaste da realidade de um "estado de natureza”, caos e fragmentação das estruturas da sociedade. Ao homem não é minimamente razoável existir como os animais ditos irracionais.

É exatamente com o viés e favorecer a harmonia social em que política e atuação éticas são colocadas, não como concepções antagônicas, mas como parceria essencial mediante a consideração de que:

o surgimento do terceiro homem deve inserir-se na perspectiva da intriga humana enquanto esta é sempre uma intriga social [...] A intriga eu-rosto em que o bem se passa na eticidade como responsabilidade pelo outro já diz respeito à aproximação do "próximo do meu próximo” (RIBEIRO JÚNIOR, 2008, p. 92)

É exatamente com o viés de favorecer a harmonia social que a política e a atuação ética são colocadas, não como concepções antagônicas, mas como elementos de colaboração entre si, para que se alcance o bem que a justiça, evidenciada com as duas, possa proporcionar a sociedade.

Pois, de um outro ponto de vista que o da filosofia política, e não somente do ponto de vista levinasiano, a política, assim como as éticas do sujeito transcendental, não detém autonomia verdadeira. Isto implica que a política, e não mais a moral no sentido dos "valores" aos quais o fato ético não deve nada, não pode julgar a partir de si o grau de universalidade de sua própria instituição. (BENSUSSAN, 2009, p. 46)

Eis a necessidade da imbricada e frutuosa relação que se estabelece com as parcerias entre ética, política e Direito na configuração da justiça. Surge, então, a propriedade dos suaves pensamentos do filósofo lituano, ao perfilhar a trajetória humana com construções intersubjetivas pautadas pela alteridade do rosto do outro, materializadas pela intriga ética no relacionamento social.

\section{O ETHOS SOCIAL: O AGIR ILUMINADO PELO VALOR ENQUANTO JUÍZO EM BUSCA DA ÉTICA}

O humano, por excelência, ao constituir, como ressaltado acima, um arcabouço de significações para compreender ou, pelo menos, buscar compreender o seu existir, passa a ter o seu modo de viver, seus comportamentos e atitudes frente às situações colocadas pela vida norteado pelo ethos, que significa

o universo de sentidos e símbolos que constituem o modo de ser e viver de um determinado sujeito. [...] O ethos é a resultante histórica da criação humana. Ele, por sua vez, reflete o conjunto de sentidos, instituições, práticas e valores simbólicos de cada subjetividade histórica e de cada sociedade [...] espelha a prática criativa de toda rede simbólica pela qual o sujeito tece sua relação com o mundo (BARTOLOMÉ RUIZ, 2006, p. 129) 


\title{
REVISTA ELETRÔNI CA DA FACULDADE DE DIREITO DE FRANCA \\ www.revista.direitofranca.br \\ v. 7, n.1, jul/ 2013, ISSN: 1983-4225
}

Percebe-se que a valoração do mundo, das coisas, dos seres e das pessoas reflete e se apresenta como resultante da configuração do ethos constituído pelo processo do existir. Dessa forma, tem-se que o ethos não apenas do Eu subjetivo, mas, também, da sociedade representa a percepção de mundo que influirá de forma subsuntiva na formação e elaboração do Estado, enquanto estrutura que engloba as subjetividades que dele fazem parte, e dos seus órgãos, notadamente, na configuração atual de Estado Democrático, os poderes Legislativo, Executivo e Judiciário, que o regulamentam e tornam possíveis a sua existência.

Apresenta-se de forma clara a importância da influência do ethos vigente e do seu reflexo no desenvolvimento das leis, políticas públicas e decisões judiciais que respondem aos apelos da sociedade. É necessário se compreender que “quando a ética do rosto reconhece a necessidade do político, a política não se desvincula do rosto.” (RIBEIRO JÚNIOR, 2008, p. 92). Consequentemente, faz-se por imperioso perceber que à configuração do ethos deve-se associar a presença da ética construída no plano de cada um(a) e das instituições criadas para a regulamentação social. Neste sentido:

\begin{abstract}
se a política é o lugar da articulação razoável, pessoa/sociedade, se ela se mantém neste lugar articulado/articulando como campo de relações, rede entrecruzada de hierarquias, isto acontece a partir de uma relação singular que a precede e que é sempre mais antiga que ela. Esta relação é o face-a-face em suas dimensões ao mesmo tempo empíricas e não empíricas. Cada elemento do lugar político não se reconduz bruscamente ao face-a-face, visto que muitas estruturas e vínculos são irredutíveis, mas dele procedem essencialmente.[...] Assim, o questionamento é inteiramente relançado em torno da relação "política", considerando bem, entre o depois da política e seu antes ético, entre o "estar junto num lugar", a comunidade tópica em que viriam se inscrever a pessoa e seus direitos, e o que não se saberia manter em nenhum lugar, a utopia do humano. (grifo nosso) (BENSUSSAN, 2009, p. 70)
\end{abstract}

Percebe-se uma característica relevante para se compreender a política enquanto atividade dada na coletividade social, que é o seu voltar-se para a célula primordial do face-a-face da qual ela surge e emerge para a coletividade de indivíduos. A sociedade surge quando da presença de mais de uma pessoa no espaço-tempo. A existência de indivíduos com necessidades e interesses diversos faz com que a política, enquanto mediadora dos interesses em tela, apresente-se como criação humana essencial para que seja possibilitada a coexistência de indivíduos distintos entre si. Possibilidade essa que adquire acentos distintos no pensamento levinasiano da clássica subserviência das singularidades ao Estado, tendo em consideração que a ontologia construída pelo filósofo lituano se pauta pelo relacionamento com o semelhante-que-diferente, essa possibilidade de coexistência em hospitalidade, como anterior às estruturas sociais. 


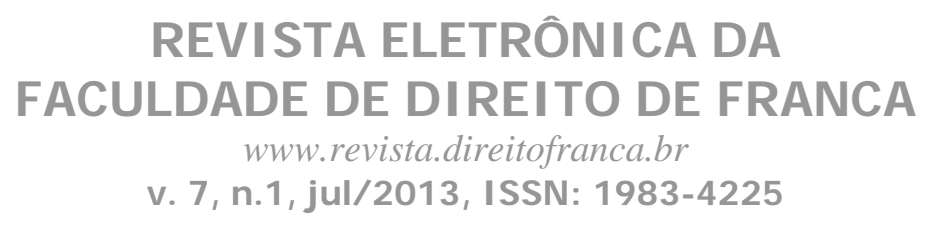

Lévinas não trata de denunciar a política enquanto tal, de considerar o Estado como fatalmente votado a ser um mal necessário. No entanto, procura refletir de um modo radicalmente diferente dos teóricos do contrato social, que pensam a necessidade do político como imposta ao pensamento no termo da constatação de uma impossibilidade de se sobreviver sem fazer um contrato. (PIMENTA, 2010, p. 10)

Pensar a política pelo momento ético em que ela pode e deve se desenvolver se configura como tarefa de importância valorativa para uma sociedade que vise o próprio desenvolvimento, na paz e harmonia, pautado pelo constante debruçar-se sobre como se dá o relacionamento desde a célula dos dois Eus em comunicação, até o nós, representado pelo terceiro, ou seja, a sociedade como um todo. A saúde de um sistema político, como estrutura que possibilita o fazer a política, deve ser verificada na base deste, ou seja, em como cada um(a) procede para a resolução de suas demandas face o outro no campo do relacionamento baseado pela lógica da razoabilidade ${ }^{8}$.

O conhecimento da norma, a liberdade de se autodeterminar diante dela, e a consciência moral, que se desenvolve no seio do ethos, que dá os critérios objetivos para a auto avaliação (subjetiva) que cada indivíduo, inserido historicamente nele, faz de seu comportamento ético, para saber se está realizando mais ou menos aquela sua "Perfeição de ser”. (BROCHADO, 2002, p. 37)

A política, assim como o Estado procedem primordialmente de indivíduos que se dispõe a uma vivência em comum, sob regras pensadas e sopesadas de forma a atender as necessidades que se apresentam. "O Estado é chamado a responder como garantidor da ordem da justiça contra a violência, contra o arbitrário da liberdade do Eu. É dever do Estado intervir de forma a trazer justiça às relações humanas.” (PIMENTA, 2010, p. 11)

Lo Stato há quindi, nel pensiero di Levinas, un significato fondamentalmente etico, che
investe precisamente l’ordinamento economico, sociale e político. [...] D’altra parte resterà
sempre uma tensione dialettica tra la responsabillità etica individuale e La eticità oggettiva
e struturale dello Stato. Proprio questa tensione dialettica svolgerà uma funzione ispiratrice
e critica dello Stato. [...] La responsabilità individuale è insostituibile. In questo senso
Levinas caratterizza tal volta la filosofia come individualismo etico.(
BURGGRAEVE,1973, p. 596)

Ainda que as estruturas políticas adquiram uma complexidade evidenciada pelas demandas de uma composição social que não mais é formada por apenas uns poucos indivíduos, devem elas sempre se reportar a este núcleo primitivo, qual seja, o outro e o Eu interpelado, do qual ela foi fundada.

\footnotetext{
${ }^{8}$ Para maior aprofundamento, Cf. SEN, Amartya. L’idée de justice. Paris: Flamarion, 2010, p. 383-399.
} 


\title{
REVISTA ELETRÔNI CA DA FACULDADE DE DIREITO DE FRANCA \\ www.revista.direitofranca.br \\ v. 7, n.1, jul/ 2013, I SSN: 1983-4225
}

Na medida em que surge a necessidade de posicionar-se a ética na configuração do ethos, implica-se, igualmente, a entrada da noção de valor que se apresenta imbricada à existência e ao desenvolvimento do comportamento ético em sociedade.

O valor, enquanto juízo que se faz pela ótica do ser existente, representa a imersão do Eu em sociedade, o que denota o caráter social do humano que se relaciona, valora o mundo e o que o integra por meio da sua compreensão desenvolvida pelo interminável processo de significação. O valor que se atribui ao ato de cumprir as leis as quais um cidadão se submete; o valor que dimensiona a noção do diferente-que-eu; o valor que se coloca a serviço de uma busca por um agir desinteressado, o egoísmo ético levinasiano ${ }^{9}$, refletem a ética que emerge das consciências e se espraia pelo tecido social. Assim, compreende-se a ética enquanto:

\begin{abstract}
uma prática e uma prática valorativa pela qual o sujeito, ao criar sentido para o mundo em que vive, se auto institui como sujeito social. Ou se quisermos, a ética é, prioritariamente, uma prática pela qual o sujeito se auto institui como tal sujeito e concomitantemente institui a sociedade em que está inserido. [...] o sentido do ethos humano é uma criação do sujeito e não uma mera descoberta de leis morais ou de normas naturais que deve cumprir para levar uma existência natural. (BARTOLOMÉ RUIZ, 2006, p. 130)
\end{abstract}

Destaque-se a elementar diferenciação entre ética e política ${ }^{10}$. Tem-se que “a ética não pode ser uma política [...] Entretanto, na medida em que ela me obriga, me acusa e me ordena como sujeito, na medida em que os terceiros estão já convidados nesta sujeição ao outro, ela tem evidentemente a ver com a política.” (BENSUSSAN, 2009, p. 94). A ética possibilita um agir político permeado pela autocrítica. Comportamento esse essencial para que se pense uma sociedade na qual as sujeições e violações de direitos dos indivíduos possam ser atenuadas, combatidas ou extirpadas pela atividade política que, em tendo como elemento valorativo a ética, torna-se apta a lidar com as diversas situações que se apresentam para serem resolvidas pela atuação na esfera pública.

Diante dessa conceituação, ressaltar-se, na esteira do pensamento levinasiano, que a autoconstituição do Eu, sua vivência, exercício e formação política, pauta-se não por uma concepção egológica, que enleva o primado do Eu. Realidade essa ensinada por Sócrates, que postulava por uma “completude” do indivíduo existente, que exerce uma liberdade focada no

\footnotetext{
${ }^{9}$ Neste sentido, tem-se que o egoísmo ético, ou, individualismo ético “não é uma impossibilidade da socialidade. Do mesmo modo, a igualdade e a justiça, na comunidade humana, são anteriores aos arquétipos estabelecidos: surgem no encontro do eu com o outro.” MELO, 2003, p. 254.

${ }^{10}$ Sobre a temática abordada, Cf. SOUSA, Ricardo Timm. Ética como fundamento - uma introdução à ética contemporânea. São Leopoldo: Editora Nova Harmonia, 2004.
} 


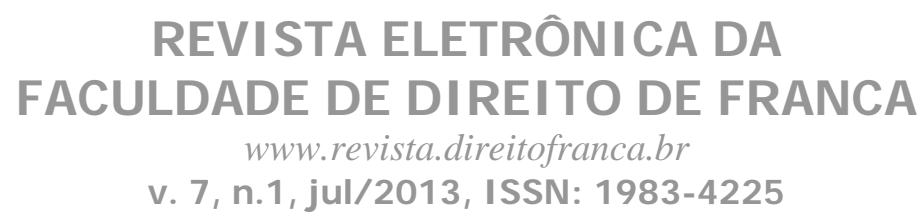

permanecer na razão que filtra o ambiente externo, de forma a amoldá-lo a percepção do Eu que se basta enquanto criador da sua autoidentidade.

\begin{abstract}
O primado do mesmo foi a lição de Sócrates: nada receber de outrem a não ser o que já está em mim, como se, desde toda a eternidade, eu já possuísse o que me vem de fora. Nada a receber ou ser livre. A liberdade não se assemelha à caprichosa espontaneidade do livrearbítrio. O seu sentido último tem a ver com a permanência no Mesmo, que é Razão. $\underline{\mathrm{O}}$ conhecimento é o desdobramento dessa identidade, é liberdade. O fato de a razão no fim de contas ser a manifestação de uma liberdade, neutralizando o outro e englobando-o, não pode surpreender, a partir do momento em que se disse que a razão soberana apenas se conhece a si própria, que nada mais a limita. A neutralização do outro, que se torna tema ou objecto - que aparece - isto é - se coloca na claridade - é precisamente sua redução ao mesmo. [...] o ideal da verdade Socrática assenta, portanto, na suficiência essencial do Mesmo, na sua identificação de ipseidade, no seu egoísmo. A filosofia é uma egologia. (grifo nosso) (LÉVINAS, 2008a, p. 30-31)
\end{abstract}

Deve-se, porém, estimular o desenvolvimento de uma visão materializada na prática valorativa que considere a alteridade como dimensão constituinte essencial que interpela constantemente o Eu para que paute sua conduta pela ética em meio ao ethos social. Essa conduta adquire, assim, conotação notadamente política, na medida em que resulta do imbricado relacionamento com o outro e suas demandas.

\title{
5. CONCLUSÃO
}

O pensamento levinasiano procurou apresentou um novo conceito de indivíduo, um novo modo de existir com o outro. A hospitalidade ao rosto do outro se configura como reflexo da responsabilidade no exercício do egoísmo ético decorrente da abertura aos apelos do vulnerável. Na liberdade de existir, o outro espera do Eu reconhecimento que dignifica e aplaca as misérias materiais e morais decorrentes das violências sofridas na sociedade. Nessa preocupação com o próximo se concretiza o bem que se espraia como justiça à sociedade, consolidando a estabilidade da democracia ao se propor uma perspectiva de aprimoramento pessoal de cada cidadão. O relacionamento pautado pela intriga ética se configura, dessa forma, como otimismo expressado no resgate de um verdadeiro humanismo que promova a realização histórico-fenomênica do humano por meio do (re)estabelecimento da sua dignidade e identidade singulares. O Direito representa um concreto instrumento de pacificação social e promoção do desenvolvimento humano, devendo ser pensado como interligado à política e à ética em parceria que se demonstra primordial para sua 


\section{REVI STA ELETRÔNI CA DA \\ FACULDADE DE DIREITO DE FRANCA \\ www.revista.direitofranca.br \\ v. 7, n.1, jul/ 2013, I SSN: 1983-4225}

tematização crítica e dialogada. A construção de um senso de justiça pautado pela alteridade cofigurou a meta que se pretendeu expor e apresentar.

\section{REFERÊNCIAS BIBLIOGRÁFICAS}

AUARD, Catherine. Cidadania e democracia deliberativa. Porto alegre: Edipucrs, 2006.

BARTOLOMÉ RUIZ, Castor M. M. As Encruzilhadas do Humanismo. Petrópolis, RJ: Vozes, 2006.

BENSUSSAN, Gérard. Ética e experiência a política em Levinas. Passo Fundo, RS: IFIBE, 2009.

BROCHADO, Mariá. Consciência moral, consciência jurídica. Belo Horizonte: Mandamentos, 2002.

BUBER, Martin. Il problema dell’uomo. Tradução de Fabio Sante Pignagnoli. Genova Milano: Marietti, 2004.

BURGgRAEVE, Roger. Il Contributo di E. Levinas al Personalismo Sociale. Salesianum. 1973.

DI SANTE, Carmine. Responsabilidade: o eu para o outro. São Paulo: Paulus, 2005.

GUSTIN, Miracy Barbosa de souza. A voz do Conselho: NECESSIDADES HUMANAS, DIREITO E POLÍTICA. Revista Governança Social - IGS, Belo Horizonte, ano 3, edição 8, p. 914, abril a julho 2010. Disponível em: <http://www.pos.direito.ufmg.br/rbep/103257284.pdf 2011>. Acesso em: 06 jun. 2012.

HÄRING, Bernhard . Moral personalista. São Paulo: Paulinas, 1974

HUTCHENS, B. C. Compreender Lévinas. Petrópolis, RJ: Vozes, 2007.

LÉVINAS, Emmanuel. Totalidade e Infinito. Lisboa, Portugal: Edições 70, 2008a.

De Deus que vem à Ideia. Petrópolis, RJ: Vozes, 2008b.

LOPES, Mônica Sette. Crash: entre encontros e desencontros. Disponível em: <http://www.amatra3.com.br/uploaded_files/crash.pdf>. Acesso em: 02 jun. 2012.

Os juízes no espelho: ver e ser visto. No prelo, 2012a.

MELO, Nélio Vieira de. A Ética da Alteridade em Emmanuel Lévinas. Porto Alegre, RS: EDIPUCRS, 2003.

O’NEILL, Onora. Em direção à justiça e à virtude. Uma exposição construtiva do raciocínio pratico. São Leopoldo: Unisinos, 2006. 


\section{REVISTA ELETRÔNI CA DA \\ FACULDADE DE DIREITO DE FRANCA}

www.revista.direitofranca.br

v. 7, n.1, jul/ 2013, ISSN: 1983-4225

PIMENTA, Leonardo Goulart. Justiça, alteridade e Direitos Humanos na teoria de Emmanuel Lévinas. Revista Direito e Humanidades, São Caetano do Sul, n. 19, jul./dez. 2010 - ISSN: 1518$594 X$.

Disponível

em

<http://seer.uscs.edu.br/index.php/revista_direito/article/view/1104/899> $>$.Acesso em: 20 jun. 2012.

RIBEIRO JÚNIOR, Nilo. Sabedoria da Paz: Ética e Teo-lógica em Emmanuel Lévinas. São Paulo, SP: Edições Loyola, 2008.

ROSENZWEIG, Franz. El nuevo pensamiento. Madrid: Visor, 1989. 